INTERNATIONAL HIGHER EDUCATION, Number 62 Winter 2011

Pages 23-25

\title{
California's Downfall:
}

Obama's Stimulus Funding Is a Lifeline, But What about Next Year?

John Aubrey Douglass

John Aubrey Douglass is senior research fellow at the Center for Studies in Higher Education at the University of California, Berkeley. E-mail: douglass@berkeley.edu. This essay is adopted from a new CSHE working paper, "Re-Imagining California's Higher Education System," available at http:/ / cshe.berkeley.edu/ publications/ publications.php?s=1.

California's famed public higher education system is undergoing a possibly significant redefinition, driven solely by severe budget cuts. Before the onset of the Great Recession, the state's tripartite system (the University of California, the California State University, and a network of nearly 110 community colleges) had been slowly starved of public funding. Over the past two decades, state funding for higher education on a per student basis has plummeted, while enrollment growth has steadily climbed. But now the trend has accelerated mightily, and the policy implications are unprecedented. 


\section{ENROLLMENT CUTS}

Built around the concept of broad access and quality academic programs, the logic of the system is eroding quickly. In the past, even in bad budget years, California's public universities and colleges accepted all eligible state students applying for admission (students who take required courses, get high grades, and do well on standardized tests). But those days may well be over. For the first time since the conception of this system in the early 20th century, the University of California (UC) and the California State University (CSU) restricted enrollment in their systems.

Last academic year, UC refused some 2,300 UC-eligible freshmen from entering its campuses-equal to a 6 percent overall reduction in the university's systemwide freshman enrollment. Adjusted for inflation and enrollment growth, state funding per student at UC has fallen nearly 40 percent since 1990-from $\$ 15,860$ in 1990 to $\$ 9,560$ today in current, inflation-adjusted dollars.

CSU, which at 450,000 is more than twice the size of UC in total enrollment, turned away an estimated 20,000 normally eligible students for admission last year, and planned another 20,000 for this 2010/11 academic year. Combined with reductions in course offerings, one estimate is that some 56,000 students will not gain access to CSU over a two-plus-year period of budget cuts. CSU's planned limit on enrollment is in reaction to successive years of major budget cuts, including a midyear cut of some $\$ 66$ million and probably larger cuts next academic year, on top of a $\$ 31.3$ million cut earlier this year.

One hope was that California's community colleges could absorb some of those students who were refused admission to UC and CSU. But these local colleges, which offer two-year associate of arts degrees and various certificates, 
have been swamped by increased demand for higher education. Before the economic crisis, these community colleges were already the most underfunded in the nation. A budget cut of $\$ 825$ million the last fiscal year led to wholesale cutting of courses, and shrinking enrollment capacity has translated into a projected 250,000 prospective community college students being denied access.

\section{EXPLAINING THE DOWNTURN}

How did this unhappy scenario transpire? Beyond the current economic collapse that has hit California particularly hard, a number of underlying macrostructural causes continue. On the one hand, rising costs for prisons and Medicaid, along with mandates for funding the state's public schools, have squeezed out state support for higher education. Public universities, UC and CSU, have the relatively low status of "discretionary" funding, given the absence of constitutional mandates to keep higher education afloat.

On the other hand, the inability of lawmakers to manage the state has magnified the problem. Prudent budget cuts, along with marginal increases in state revenues in better economic times, would have mitigated the huge cuts faced today. In no small measure, the state budget process has been held hostage by right-wing, antigovernment ("starve the beast") conservatives empowered by the unusual requirement of a two-thirds vote to pass a budget in the State Assembly. There is blame to go around, that is for sure; but the fact remains that a small group of politicians in safe, heavily conservative districts have been running the budget show.

Raising fees and tuition have formed one policy lever employed to mitigate the state budget cuts. The Obama administration's economic stimulus 
package has also funneled much-needed funds to education, including some $\$ 640$ million to UC and CSU and another $\$ 160$ million to local community colleges.

But neither income source is large enough to offset the dropping of courses, staff and faculty layoffs, cuts in salaries, and ultimately reductions in enrollment. California's state government, and its public higher education system, was at the edge of a cliff of total fiscal collapse; the stimulus bill averted a complete implosion. But it remains largely a one-year fix with some $\$ 7.97$ billion for California's public schools and higher education system during this fiscal year $(2009 / 10)$. But because of the severity of the budget problems for higher education, all available stimulus funds for education will have been mostly spent the last academic year, forming a substantial financial hole for 2010/11.

California is already ranked among the bottom states in the number of students who enter higher education and then attain a bachelor's degree. It seems evident that California will now have a significant, further decline in the educational attainment level of its population.

But beyond the immediate effects of educational aspirations denied, and the disproportional effects it will have on lower and middle-income students and their families, the real possibility is under way of an unraveling of California's famed coherent approach to higher education. Currently, no consensus or political leadership appears to solve the long-term consequences of this dramatic breakdown in California's famed higher education system.

The size of California's 2011 state budget deficit, some $\$ 19$ billion, means a small prospectus that large-scale budget relief is around the corner. States have very limited ability to borrow funds for operating costs, making the federal 
government the last resort. In short, how state budgets go, so goes US higher education; whereas most national systems of higher education financing are tied to national budgets with an ability to borrow.

\section{LOOKING INTO THE FUTURE}

In the first glimmer of some improvement in the public funding for higher education in California, lame-duck Governor Arnold Schwarzenegger signed a much-delayed state budget in October 2010, which restores about \$199 million, each, to UC and CSU. Combined with a decision to spend much of what little remains of federal stimulus funding for California, both UC and CSU will get an infusion of some $\$ 610$ million over last year.

But this still leaves both systems some $\$ 664$ million below their budget allocation in $2007 / 08$. Community colleges received a smaller increase of about 5 percent in the budget deal. Many expect midyear corrections by a new governor as the budget is based on optimistic projections of state revenue, including a presumed $\$ 5.5$ billion of federal funds to help close the $\$ 19$ billion state deficit. The new budget includes no new taxes and relies on $\$ 7.5$ billion in spending cuts and deferred funding payments to $\mathrm{K}-12$ schools and community colleges.

California's plight is perhaps the worst among the US states, but similar stories can be found throughout the nation, with a deleterious effect on access, time-to-degree, degree production, and the morale of faculty and staff at public universities and colleges. Among competitors in the Organization for Economic Cooperation and Development, perhaps only England and Ireland's higher education systems are facing a similar magnitude of austerity cuts. But one big 
difference in California is that its population is growing-from a current 37 million to a projected 60 million in 2050.

One might postulate that the decisions made today and in reaction to the "Great Recession" by nations will likely speed up global shifts in the race to develop human capital, with the United States probably losing some ground.

There is the real prospect that bachelor degree attainment rates in the United States will dip in the near term, particularly in states like California that have substantially reduced access to higher education even as enrollment demand has gone up. Even with an eventual world economic recovery, it appears that in states such as California a full recovery of public funding is unlikely for public colleges and universities.

We are in the midst of reorganization and redefinition of this famed system with no clear sense of its ultimate outcome. Ironically, 2010 marks the 50th anniversary of California's Master Plan for Higher Education, formulated in 1960. The master plan helped guide the expansion of an already tremendously successful higher education system. That was a proactive effort to balance mass higher education with a high-quality and highly differentiated network of colleges and universities. What we are experiencing now in California is highly reactive.

How can California once again be placed in the vanguard of supporting and growing a mass system of higher education? In a new working paper informed by the history of the tripartite system, its strengths and weaknesses over time, and the reform efforts of economic competitors throughout the world who are making significant investments in their own tertiary institutions, I offer a "re-imagined" network of colleges and universities and a plan for "smart 
growth." My desire is to start a debate on what would be the next logical phase in the further development of California's network of colleges and universities. 